\title{
KARAKTERISASI MORFOLOGI DAN HASIL TANAMAN KENTANG VARIETAS GRANOLA DAN KENTANG MERAH YANG DIBUDIDAYAKAN DI BENER MERIAH PROVINSI ACEH
}

\section{Morphological Characterization And Yield Of Granola And Red Potato Varieties Cultivated In Bener Meriah, Aceh Province}

\author{
Ismadi $^{1 *}$, Kholilah Annisa ${ }^{1}$, Laila Nazirah ${ }^{1}$, Nilahayati ${ }^{1}$ dan Maisura ${ }^{1}$ \\ ${ }^{1}$ Program Studi Agroekoteknologi Fakultas Pertanian Universitas Malikussaleh \\ Kampus Reuleut, Aceh Utara, Aceh, Indonesia \\ "Corresponding author: ismadi@unimal.ac.id
}

\begin{abstract}
Potatoes are a horticultural crop that is very popular with people, containing carbohydrates and high nutritional value. This research was conducted in Ujung Gele Village, Bukit Subdistrict, Bener Meriah Regency with an altitude of 1300 masl from July to November 2020. The purpose of this study was to determine the morphological characteristics of the Granola and red potato varieties cultivated in accordance with the technical guidelines for potato cultivation by the West Java Agricultural Technology Research Institute in 2015. The observed characteristics followed the International Union method for The Protection of New Varieties of Plants (UPOV, 2004) which consists of 32 Characteristics. Observations consisted of shoots, stems, leaves, flowers, fruit, harvest age, tubers and yield potential at different times. Shoots were observed before planting, stems, leaves, flowers, and fruits were observed during growth and finally the tubers were observed after harvest. The results showed that each variety had different morphological characteristics from other varieties. The Granola variety has yellow bulbs and blue violet flowers, while the red potato variety has red tubers and red violet flowers. The calculation of yield potential showed that the Granola and red potato varieties had high yields reaching 25.874 tonnes/ha (Granola) and 28.671 tonnes/ha (red potatoes).
\end{abstract}

Keywords: shoots, stem, leave, flower, tuber

\section{ABSTRAK}

Kentang merupakan salah satu tanaman hortikultura yang disukai masyarakat karena mengandung karbohidrat dan nilai gizi yang tinggi. Penelitian ini dilakukan di Desa Ujung Gele Kecamatan Bukit Kabupaten Bener Meriah dengan ketinggian 1300 mdpl mulai Juli hingga November 2020. Tujuan dari penelitian ini adalah untuk mengetahui karakteristik morfologi varietas Granola dan kentang merah yang dibudidayakan sesuai dengan pedoman teknis budidaya kentang oleh Balai Penelitian Teknologi Pertanian Jawa Barat tahun 2015. Karakteristik yang diamati mengikuti metode the International Union method for The Protection of New Varieties of Plants (UPOV, 2004) yang terdiri dari 32 karakteristik. Pengamatan meliputi tunas, batang, daun, bunga, buah, umur panen, umbi dan potensi hasil pada waktu yang berbeda. Tunas diamati sebelum tanam, batang, daun, bunga, dan buah diamati selama pertumbuhan dan terakhir umbi diamati setelah panen. Hasil penelitian menunjukkan bahwa setiap varietas memiliki karakteristik morfologi yang berbeda dengan varietas lainnya. Varietas Granola memiliki umbi kuning dan bunga violet biru, sedangkan varietas kentang merah memiliki umbi merah dan bunga violet merah. Perhitungan potensi hasil menunjukkan bahwa varietas Granola dan kentang merah memiliki hasil yang tinggi yaitu 25.874 ton/ha (Granola) dan 28.671 ton/ha (kentang merah).

Kata Kunci: tunas, batang, daun, bunga, umbi 


\section{PENDAHULUAN}

Kentang merupakan salah satu komoditas penting dan mendapat prioritas untuk dikembangkan di Indonesia (Duriat et al., 2006) karena memiliki potensi untuk diekspor ke negara lain. Tanaman ini termasuk tanaman pangan utama keempat dunia, setelah padi, gandum dan jagung (Asgar, 2013). Tanaman kentang digolongkan ke dalam tanaman sayuran di Indonesia. Kentang kaya akan nilai gizi diantaranya banyak mengandung karbohidrat, mineral, dan vitamin sehingga dapat dijadikan sebagai sebagai sumber karbohidrat dan berpotensi dalam diversifikasi pangan (Karjadi dan Buchory, 2008).

Dalam pengembangan tanaman kentang di suatu daerah, salah satu yang harus diperhatikan adalah tentang morfologinya. Morfologi tumbuhan adalah ilmu yang menyelidiki dan membandingkan bentuk dan struktur tumbuhan yang menjadi dasar penafsiran terdapatnya perbedaan diantara berbagai tanaman dan mempelajari susunan tubuh tumbuhan yang berupa kormus. Kormus merupakan tubuh tumbuhan yang dengan nyata memperlihatkan diferensiasi dalam tiga bagian pokok, yaitu akar, batang, dan daun.

Karakterisasi dan identifikasi sudah banyak dilakukan oleh peneliti sebagai dasar untuk pengembangan tanaman. Hal ini pernah dilakukan pada tanaman jahe oleh Zahra (2018), durian (Kurniadinata et al., 2020), pamelo (Yunus et al., 2018), nenas (Hernita, et al., 2019), alpukat (Handayani et al., 2018), durian (Handayani, et al., 2017; \& 2018). Karakterisasi pada tanaman sangat besar manfaatnya juga untuk membedakan tanaman yang satu dengan yang lain.

Fokus penelitian ini adalah mengidentifikasi karakteristik morfologi dan hasil tanaman kentang varietas Granola dan Kentang merah dari tunas, batang, daun, bunga, dan umbi sesuai dengan panduan International Union For The Protection Of New Varietes Of Plants) TG/23/6 2004 (UPOV, 2004). UPOV merupakan sebuah lembaga Internasional yang melindungi keberadaan suatu varietas baru tanaman, di mana Indonesia menjadi salah satu anggotanya.

\section{METODE PENELITIAN}

Penelitian ini dilaksanakan di Desa Ujung Gele Kecamatan Bukit Kabupaten Bener Meriah dengan ketinggian 1300 mdpl. Penelitian ini dilaksanakan dari Juli sampai November 2020. Alat yang digunakan dalam penelitian yaitu cangkul, garu, gembor, tali rafia, kaleng susu bekas, ajir, kamera, alat tulis, timbangan analitik, dan alat pengukur. Bahan yang digunakan yaitu bibit kentang varietas Granola dan kentang merah, pupuk kandang sapi, pupuk Urea, pupuk SP-36, pupuk $\mathrm{KCl}$, dan bagian vegetatif tanaman yang terdiri dari akar, batang, daun, bunga dan umbi diambil dari tanaman yang dibudidayakan di Bener Meriah Provinsi Aceh.

Metode penelitian dilakukan dengan metode observasi, yaitu dengan melakukan pengamatan langsung terhadap tanaman yang ditanam dengan mengidentifikasi karakteristik morfologi tanaman kentang. Proses perawatan dan pemberian pupuk didasarkan pada BPTP Jawa Barat (2015). Pengambilan data dilakukan dengan mengumpulkan data dari sampel berdasarkan buku panduan deskriptor kentang UPOV TG/23/6 (2004).

Peubah yang diamati terdiri dari 32 jenis, yaitu ukuran tunas, bentuk tunas, ukuran ujung tunas, pola pertunasan, panjang tunas lateral, tinggi tanaman, tipe pertumbuhan, pola tumbuh, ketebalan batang utama, ukuran daun, susunan daun, ukuran anak daun, lebar anak daun, frekuensi daun menyimpang, kilap daun bagian atas, frekuensi daun sekunder, frekuensi daun sekunder pada terminal daun, frekuensi daun sekunder pada lateral daun, ukuran daun sekunder, ukuran tandan bunga, frekuensi berbunga, warna bagian dalam mahkota bunga, ukuran mahkota bunga, frekuensi buah, umur panen, bentuk umbi, kedalaman mata, kulit umbi, warna kulit, warna pangkal mata tunas, warna daging umbi, dan potensi hasil.

\section{HASIL DAN PEMBAHASAN}

\section{Ukuran, Bentuk dan Panjang Tunas Bibit}

Pengamatan pertama dilakukan pada bagian tunas bibit yang diamati sebelum umbi bibit ditanam, mulai dari ukuran, bentuk, panjang, dan pola pertunasan. Bibit varietas 
kentang Granola memiliki ukuran tunas yang lebih pendek dari kentang merah dengan ratarata ukuran tunas $1,15 \mathrm{~cm}$, bentuk tunas ovoid, ukuran ujung tunas rata-rata $0,2 \mathrm{~cm}$, pola pertunasan tertutup, dan memiliki tunas lateral yang lebih pendek. Bibit varietas kentang merah memiliki ukuran tunas $2,41 \mathrm{~cm}$, tunasnya berbentuk narrow cylindrical, dengan ukuran ujung tunas rata-rata $0,3 \mathrm{~cm}$. Pola pertunasannya bibit sama antara kentang Granola dan kentang merah yakni tertutup. Bibit kedua jenis kentang tersebut memiliki panjang tunas lateral yang pendek.

Bibit tunas pada tanaman kentang terdiri dari lima bentuk, yaitu spherical, ovoid, conical, broad cylindrical, dan narrow cylindrical. Bibit tunas varietas kentang
Granola adalah conica, yang berbentuk seperti kerucut, sedangkan kentang merah berbentuk narrow cylindrical, yang berbentuk silinder sempit. Pola pertunasan bibit tanaman kentang ada tiga bentuk yaitu tertutup, sedang, dan terbuka (UPOV, 2004). Bibit kedua varietas kentang yang diteliti memiliki pola pertunasan yang sama yakni tertutup, dimana bagian ujung tunas tidak mekar.

Hasil penelitian pada kedua bibit kedua varietas memiliki tunas lateral yang pendek. Panjang tunas bibit kentang itu sendiri ada tiga ukuran yaitu pendek, sedang, dan panjang. Tunas lateral adalah tunas yang memanjang dari samping tunas utama. Struktur tunas bibit tanaman kentang seperti ditampilkan pada Gambar 1.

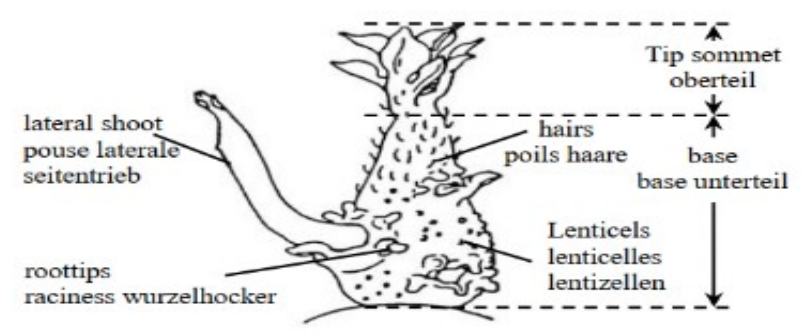

Gambar 1. Struktur tunas (UPOV, 2004).

Tinggi, Tipe dan Pola Pertumbuhan, dan Ketebalan Batang Utama

Pengamatan pada bagian batang tanaman terdapat empat karakteristik, yaitu tinggi tanaman, tipe dan pola pertumbuhan, dan ketebalan batang utama. Tinggi tanaman diukur mulai di atas permukaan tanah sampai titik tumbuh menggunakan penggaris. Tipe pertumbuhan, pola tumbuh yang diamati menggunakan acuan gambar oleh UPOV (2004), dan ketebalan batang utama yang dibagi menjadi tiga tingkatan ukuran yaitu tegak, agak tegak, dan menyebar.

Hasil pengamatan didapati tanaman kentang varietas Granola memiliki batang 44,5 $\mathrm{cm}$, sedangkan varietas kentang merah memiliki tinggi tanaman rata-rata $61,7 \mathrm{~cm}$. Menurut UPOV (2004), varietas kentang granola ini masuk katagori sangat pendek, sedangkan varietas kentang merah masuk katagori sangat tinggi (Tabel 1). Tiga karakter lain yang diamati yaitu tipe pertumbuhan, pola tumbuh, dan ketebalan batang utama tebal diketahui bahwa terdapat kesamaan antara kentang varietas Granola dengan kentang merah. Tipe pertumbuhan kedua varietas tersebut adalah sedang dengan pola tumbuh menyebar, dan ketebalan batang utama tebal dengan rata-rata $1,2 \mathrm{~cm}$.

Pola tumbuh tanaman kentang dibagi menjadi tiga bagian yaitu tegak, agak tegak, dan menyebar. Pola tumbuh tanaman kentang varietas Granola dan kentang merah yaitu menyebar, cabang yang tumbuh tidak tegak ke atas. Tanaman kentang memiliki warga yang berbeda, tergantung varietasnya. Namun pada umumnya batang tanaman kentang berwarna hijau. Tanaman kentang berdaun majemuk yang memiliki bentuk, ukuran, dan warna yang berbeda antar varietas yang satu dengan yang lain (Hidayat, 2014). 


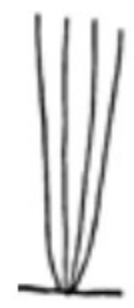

3
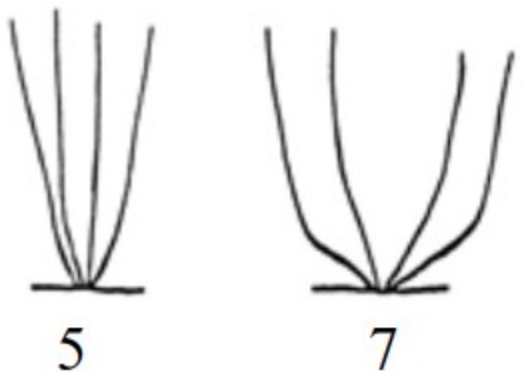

Gambar 2. Pola tumbuh (UPOV, 2004).

\section{Karakteristik Daun}

Varietas Granola memiliki panjang daun sebesar 11,6 $\mathrm{cm}$ dengan susunan daun sedang. Ukuran anak daun tergolong kecil yani $3,5 \mathrm{~cm}$, frekuensi daun sekunder 12 daun, frekuensi daun sekunder pada terminal daun sebanyak 8 daun, pada lateral daun sebanyak 4 daun, dan ukuran daun sekunder besar $1,5 \mathrm{~cm}$. Sedangkan varietas kentang merah memiliki ukuran daun $14,1 \mathrm{~cm}$ dan susunan daun terbuka. Ukuran anak daun termasuk kategori sedang yakni $4 \mathrm{~cm}$, Kentang merah memiliki frekuensi daun sekunder 10 daun, frekuensi daun sekunder pada terminal daun 8 daun dan pada lateral daun 2 daun, serta memiliki ukuran daun sekunder besar $1,8 \mathrm{~cm}$. Frekuensi daun menyimpang pada kentang varietas granola dan kentang merah jarang terjadi. Permukaan atas daun yang dimiliki kedua varietas ini adalah redup (Tabel 1).

Susunan daun tanaman kentang terdiri dari tiga bentuk yaitu tertutup, sedang, dan terbuka. Susunan daun pada tanaman kentang varietas granola dan kentang merah adalah sedang. Lebar anak daun dibagi menjadi tiga bagian, yaitu sempit, sedang, dan lebar. Dari hasil pengamatan yang dilakukan diketahui bahwa varietas kentang Granola dan kentang merah memiliki lebar anak daun yang sama yaitu sempit. Anak daun merupakan helaian dari tiap-tiap helaian daun dari daun majemuk (Tabel 2).

Frekuensi terjadinya daun menyimpang pada tanaman kentang dibagi menjadi tiga katagori yaitu jarang, sedang, dan tinggi. Hasil penelitian diketahui bahwa jarang sekali terjadi daun menyimpang pada kedua jenis kentang yang diteliti. Daun menyimpang merupakan daun yang tumbuh tidak sesuai pada tangkainya. Daun tanaman adalah organ yang sangat penting pada proses fotosintesis. Kriteria daun kentang yang diharapkan adalah banyak dan berukuran besar. Dari segi ukuran, daun kentang varietas Granola lebih panjang daripada ukuran daun varietas kentang atlantik dan Sulawesi selatan (Hidayat, et al. 2018).

\section{Bunga dan Buah}

Tandan bunga kentang varietas Granola berukuran $0,2 \mathrm{~cm}$ dengan empat bunga (Tabel 1). Mahkota bunga berukuran $1,3 \mathrm{~cm}$ dan bagian dalam mahkota bunga berwarna violet biru dan buahnya berjumlah empat (Tabel 2). Varietas kentang merah memiliki ukuran tandan bunga $0,25 \mathrm{~cm}$ dan memiliki delapan bunga serta bagian dalam mahkota bunga berwarna violet merah. Tanaman kentang merah memiliki 11 buah. Buah tanaman kentang berbentuk bulat yang terdapat dalam tandan yang berukuran sebesar kelereng. Buah ketika muda berwarna hijau dan berubah menjadi hitam setelah tua. Setiap buah memiliki lebih dari 500 biji yang berwarna putih kekuningan (Sunarjono, 2007).

\section{Umur Panen}

Umur panen tanaman kentang dibagi menjadi lima tingkatan, yaitu sangat genjah, genjah, sedang, dalam, dan sangat dalam. Tanaman kentang varietas Granola dan kentang merah berumur sedang dimana dapat dipanen pada umur 85 hari setelah tanam (Aisyah et al., 2016). Ciri tanaman yang siap panen adalah adanya perubahan warna tanaman menjadi kuning dan kering. Tanaman kentang yang siap dipanen memasuki fase pemasakan umbi dimana terjadi perubahan warna vena daun yang menguning dan kemudian akan rontok, terjadi penurunan proses fotosintesis, pertumbuhan umbi akan 
melambat dan akhirnya vena daun akan mati (Zulkarnain, 2010).

\section{Bentuk Umbi}

Pengamatan karakteristik bagian umbi dilakukan setelah pemanenan dan umbi kentang dibersihkan dari tanah dan kotoran. Varietas Granola memiliki bentuk umbi oval memendek, kedalaman mata dangkal, dan kulit umbi sedang. Kentang varietas Granola memiliki warna kulit kuning, warna pangkal mata tunas kuning, dan warna daging umbi kuning. Varietas kentang merah memiliki bentuk umbi oval memanjang, dan kedalaman mata sedang. Kulit umbi kentang merah sedang, warna kulit merah, warna pangkal mata tunas merah, dan warna daging umbi kuning tua (Tabel 2).

Tanaman kentang memiliki bentuk umbi, warna daging umbi, warna kulit umbi, dan mata tunas bervariasi menurut varietas. Umbi kentang dapat berbentuk bulat, lonjong, meruncing, atau mirip ginjal, dan memiliki ukuran yang bervariasi antara satu dengan lainnya (UPOV, 2004). Umbi kentang varietas Granola berbentuk lonjong atau oval dengan mata tunas yang dangkal, warna kulit umbi dan daging umbi kuning. Daging umbi varietas Granola memiliki warna lebih pucat atau kuning muda, sedangkan warna daging umbi pada varietas kentang merah memiliki warna lebih gelap atau kuning tua. Sitanggang (2013), mengatakan bahwa umbi varietas Granola berbentuk oval, memiliki mata umbi agak dalam, permukaan kulit umbinya halus dengan warna kulit umbi kuning dan putih, dan warna daging umbi kuning. Karakter bentuk sangat berkaitan dengan berat umbi atau produktivitasnya (Nurchayati, et al., 2019).

\section{Potensi Hasil}

Pengamatan potensi hasil dilakukan untuk mengetahui hasil produksi yang didapatkan, apakah sudah memenuhi target atau tidak. Potensi hasil yang didapatkan pada varietas granola sebesar 25,874 ton/ha dan varietas kentang merah sebesar 28,671 ton/ha. Tanaman kentang yang pada fase pertumbuhan vegetatif sangat baik akan menghasilkan umbi dengan ukuran yang lebih besar (Wulandari, et al. (2014).

Jenis varietas yang digunakan akan sangat menentukan produksi kentang. Kentang varietas granola di Indonesia saat ini memiliki potensi hasil sebesar 26,5 ton ha/ha (Neni et al., 2019). Namun pada kenyataannya, produktivitas tanaman kentang di Indonesia hanya sebesar 19,27 ton/ha dan jumlah produksi nasional sebesar 1.314 .65 ton yang dibudidayakan pada lahan seluas 68.223 ha (Pertanian.go.id, 2020). Rendahnya produktivitas karena rendahnya kualitas dan kuantitas benih kentang, pengendalian hama dan penyakit yang belum maksimal, dan masih terbatasnya kultivar kentang yang sesuai untuk kebutuhan pasar dan lingkungan tumbuh (Nuraini, 2016).

Tabel 1. Hasil pengamatan karakteristik morfologi tanaman kentang varietas Granola dan Kentang merah.

\begin{tabular}{|c|c|c|c|}
\hline \multirow{2}{*}{ Pengamatan } & \multirow{2}{*}{ Karakteristik } & \multicolumn{2}{|c|}{ Varietas } \\
\hline & & Granola & Kentang Merah \\
\hline \multirow[t]{5}{*}{ Tunas } & Ukuran Tunas & $1,15 \mathrm{~cm}$ & $2,41 \mathrm{~cm}$ \\
\hline & Bentuk Tunas & Ovoid & Narrow Cylindrical \\
\hline & Ukuran Ujung Tunas & $0,2 \mathrm{~cm}$ & $0,3 \mathrm{~cm}$ \\
\hline & Pola Pertunasan & Tertutup & Tertutup \\
\hline & Panjang Tunas Lateral & Pendek & Pendek \\
\hline \multirow[t]{4}{*}{ Batang } & Tinggi Tanaman & Sangat Pendek $(44,5 \mathrm{~cm})$ & Sangat Tinggi $(61,7 \mathrm{~cm})$ \\
\hline & Tipe Pertumbuhan & Sedang & Sedang \\
\hline & Pola Tumbuh & Menyebar & Menyebar \\
\hline & Ketebalan Batang Utama & Tebal & Tebal \\
\hline \multirow[t]{3}{*}{ Daun } & Ukuran Daun & $11,6 \mathrm{~cm}$ & $14,1 \mathrm{~cm}$ \\
\hline & Susunan Daun & Terbuka & Sedang \\
\hline & Ukuran Anak Daun & $\operatorname{Kecil}(3,5 \mathrm{~cm})$ & Sedang $(4,0 \mathrm{~cm})$ \\
\hline
\end{tabular}




\begin{tabular}{llll} 
& Lebar Anak Daun & Sempit & Sempit \\
& Frekuensi Daun Menyimpang & Jarang & Jarang \\
& Kilap Daun Bagian Atas & Redup & Redup \\
& Frekuensi Daun Sekunder & 12 Daun & 10 Daun \\
& $\begin{array}{l}\text { Frekuensi Daun Sekunder pada } \\
\text { Terminal Daun }\end{array}$ & 8 Daun & 8 Daun \\
& Frekuensi Daun Sekunder pada & 4 Daun & 2 Daun \\
& Lateral Daun & & \\
& Ukuran Daun Sekunder & Besar $(1,5 \mathrm{~cm})$ & Besar $(1,8 \mathrm{~cm})$ \\
& Ukuran Tandan Bunga & $0,2 \mathrm{~cm}$ & $0,25 \mathrm{~cm}$ \\
\hline Bunga dan & Frekuensi Berbunga & 4 Bunga & 8 Bunga \\
Buah & Ukuran Mahkota Bunga & $1,3 \mathrm{~cm}$ & $1,4 \mathrm{~cm}$ \\
& Warna Bagian Dalam Mahkota & Violet Biru & Violet Merah \\
& Bunga & & \\
& Frekuensi Buah & 4 Buah & 11 Buah \\
\hline Umur Panen & Umur Panen & Sedang $(85 \mathrm{HST})$ & Sedang $(85 \mathrm{HST})$ \\
\hline Umbi & Bentuk Umbi & Oval Memendek & Oval Panjang \\
& Kedalaman Mata & Dangkal & Sedang \\
& Kulit Umbi & Sedang & Sedang \\
& Warna Kulit & Kuning & Merah \\
& Warna Pangkal Mata Tunas & Kuning & Merah \\
& Warna Daging Umbi & Kuning & Kuning Tua \\
\hline
\end{tabular}

Tabel 2. Gambar pengamatan bagian kentang varietas Granola dan Kentang merah.

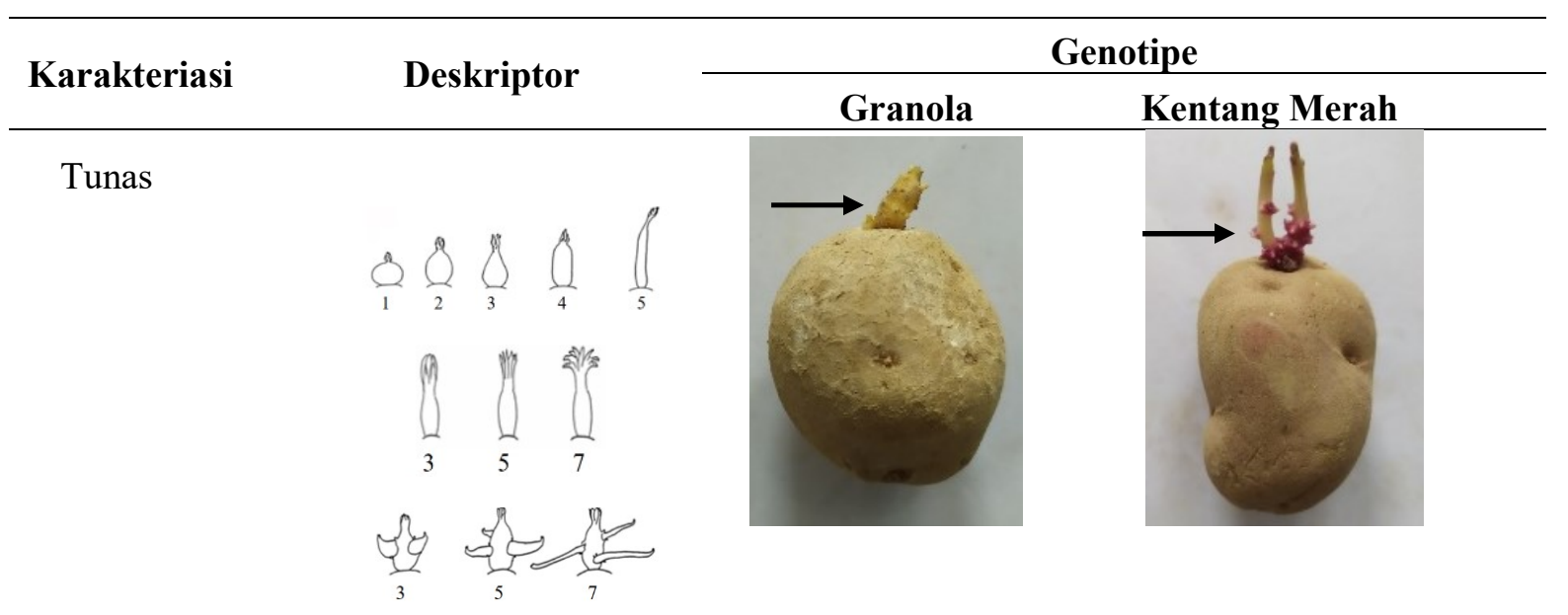

Batang
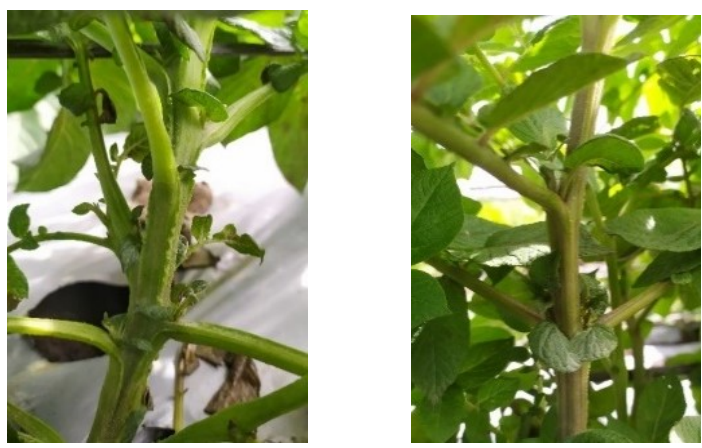
Jurnal Agrium

online version: https://ojs.unimal.ac.id/index.php/agrium

P-ISSN 1829-9288. E-ISSN 2655-1837
Maret, 2021

Vol. 18, No1

Hal. 63-71

Author(s): Ismadi, et al

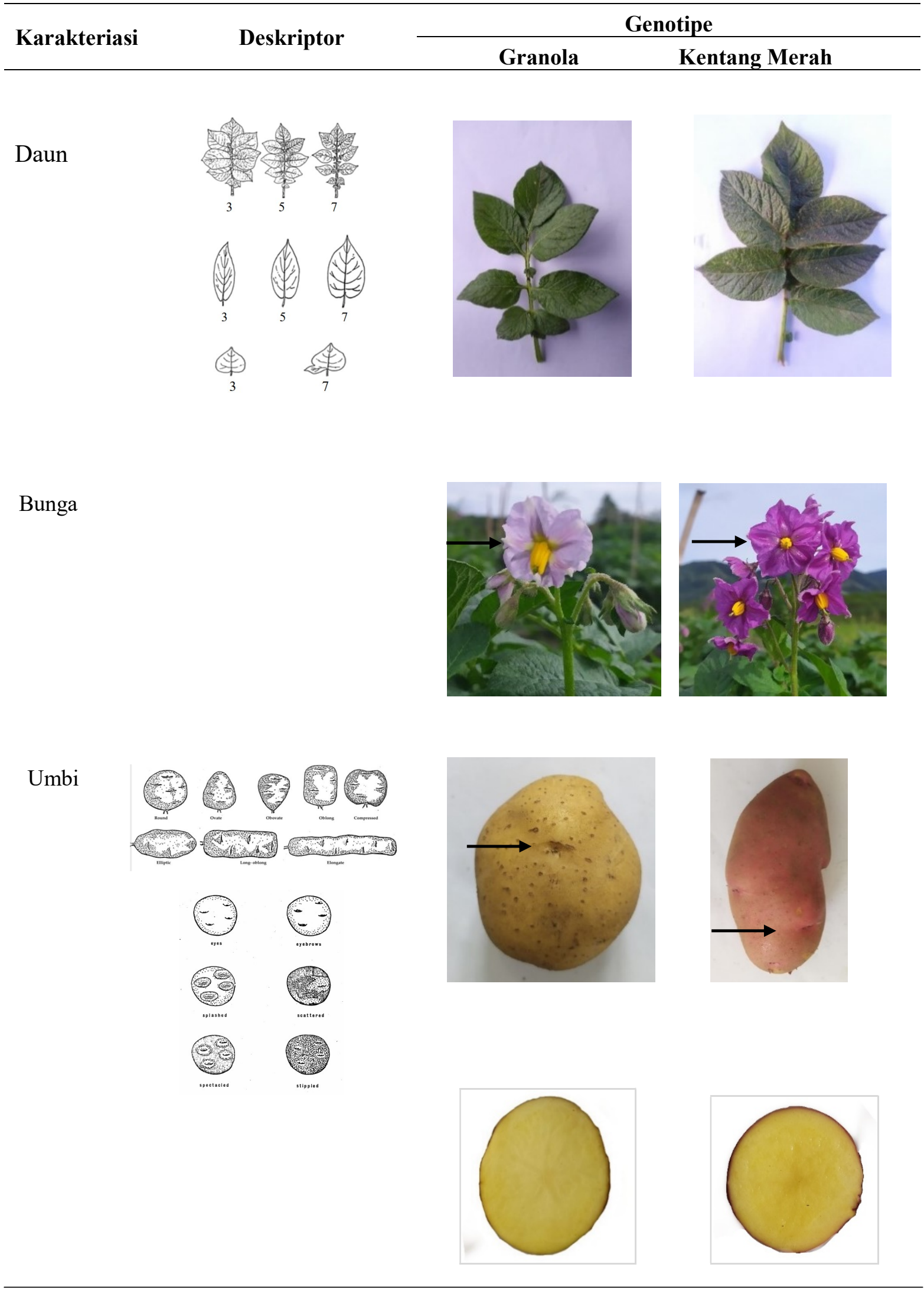


Jurnal Agrium

online version: https://ojs.unimal.ac.id/index.php/agrium P-ISSN 1829-9288. E-ISSN 2655-1837

\section{KESIMPULAN}

1. Karakteristik morfologi kentang varietas Granola yaitu bentuk tunas ovoid, pola pertunasan tertutup, tunas lateral pendek, tinggi tanaman sangat pendek, tipe pertumbuhan sedang, pola tumbuh menyebar, batangnya tebal, susunan daun terbuka, ukuran anak daun kecil, bagian dalam mahkota bunga berwarna violet biru, umur panen sedang, bentuk umbi oval memendek, kedalaman mata dangkal, warna kulit kuning, dan warna daging umbi kuning.

2. Karakteristik morfologi kentang merah yaitu bentuk tunas narrow cylindrical, pola pertunasan tertutup, tunas lateral pendek,

3. tanaman sangat tinggi, tipe pertumbuhan sedang, pola tumbuh menyebar, batang utamanya tebal, susunan daun sedang, ukuran anak daun sedang, bagian dalam mahkota berwarna violet merah, umur panen sedang, bentuk umbi oval panjang, kedalaman mata sedang, warna kulit merah, dan daging umbi berwarna kuning tua.

4. Potensi hasil tanaman kentang varietas Granola sebesar 25, 874 ton/ha dan kentang merah sebesar 28,671 ton/ha.

\section{DAFTAR PUSTAKA}

Aisyah., Mawardi., dan Nurasiah. 2016. Budidaya Kentang di Dataran Tinggi Gayo tahun 1945-2015. Jurnal Ilmiah Mahasiswa Pendidikan Sejarah (1), hal 156-171.

Asgar, A. 2013. Umbi Kentang (Solanum tuberosum L.) Klon 395195.7 Dan CIP 394613.32 Yang Ditanam Di Dataran Medium Mempunyai Harapan Untuk Keripik. Balai Penelitian Tanaman Sayuran. Bandung.

Badan Pusat Statistik (BPS). 2017. Statistik Tanaman Sayuran dan Buah-buahan Semusim Indonesia. Katalog BPS 5205009 diakses dari http://www.bps.go.id/, pada tanggal 22 Juni 2020

[BPTP] Balai Pengkajian Teknologi Pertanian, Kementerian Pertanian. 2015. Petunjuk
Maret, 2021

Vol. 18, Nol

Hal. 63-71

Author(s): Ismadi, et al

Teknis Budidaya Kentang. Balai Pengkajian Teknologi Pertanian Kementerian Pertanian. Jawa Barat.

Duriat, A.S., O.S. Gunawan, N. Gunaeni. 2006. Penerapan Teknologi PHT Pada Tanaman Kentang. Balai Penelitian Tanaman Sayuran (Balitsa), Bandung.

Handayani, R. S. dan Ismadi. 2017. Analisis Keragaman Kualitas Buah Durian Unggulan (Durio zibethinus) Aceh Utara. Jurnal Hortikultura Indonesia, 8(3), 147-154.

Handayani, R. S. \& Ismadi. 2018a. Inventory and Morphological Characterization of Durian (Durio zibethinus) in Langkahan and Sawang Sub-District of North Aceh Indonesia. In Proceedings of MICoMS 2017. Emerald Publishing Limited.

Handayani, R. S., Ismadi, \& Fahrezi, I. (2018). Exploration and Morphological Characterization of Vegetative Part of Avocado at Bebesan Subdistrict Central Aceh District, Indonesia. In Proceedings of MICoMS 2017. Emerald Publishing Limited.

Hernita, D., Salvia, E., \& Bobihoe, J. 2019. Characterization of morphology and potential of pineapple genetic resources in peatland of Jambi Province. Journal of Tropical Horticulture, 2(1), 24-28.

Hidayat, Y. S. 2014. Karakterisasi Morfologi Beberapa Genotipe Kentang (Solanum tuberosum L.) yang dibudidayakan di Indonesia. Skripsi. Institut Pertanian Bogor.

Hidayat, Y.S., Efendi, D., Sulassih. 2018. Karakterisasi Morfologi Beberapa Genotipe Kentang (Solanum tuberosum L.) yang Dibudidayakan di Indonesia. Comm. Horticulturae J. 2(1): 28-34.

Karjadi, A. K. dan A. Buchory. 2008. Pengaruh Auksin dan Sitokinin Terhadap Pertumbuhan dan Perkembangan Jaringan Meristem Kentang Kultivar Granola. Jurnal Hortikultura. 18(4):380-384.

Kementerian Pertanian Republik Indonesia. 2020. Data Lima Tahun Terakhir Subsektor Hortikultura (Horticulture Sub- 
Jurnal Agrium

online version: https://ojs.unimal.ac.id/index.php/agrium P-ISSN 1829-9288. E-ISSN 2655-1837

sector).

https://www.pertanian.go.id/home/?show= page\&act $=$ view\&id=61. Diakses 15 Maret 2021.

Kurniadinata, O. F., Wenpei, S., \& Rusdiansyah, R. 2020. Morphological Characteristics of Batuah Red-Fleshed Durian (Durio graveolens), an Endemic Exotic Plant from East Kalimantan, Indonesia. Journal of Tropical Horticulture, 3(1), 12-18.

Nuraini, A. 2016. Rekayasa Source-Sink Dengan Pemberian Zat Pengatur Tumbuh Untuk Meningkatkan Produksi Benih Kentang Di Dataran Medium Desa Margawati Kabupaten Garut. Jurnal Kultivasi. 15(1): 3-6.

Neni, N., Maharijaya. A., Syukur, M. 2018. Keragaan Produksi Kentang G2 Genotipe IPB Asal Stek dan Umbi di Garut Jawa Barat. Buletin Agrohorti. 6 (3): 397 - 404 397.

Sitanggang, M. 2013. Respon Pertumbuhan dan Produksi Bibit Kentang (Solanum tuberosum L). Skripsi. Universitas Sumatera Utara. Medan.

Sunarjono, H. 2007. Petunjuk Praktis Budidaya Kentang. Agromedia Pustaka. Jakarta.

UPOV. 2004. Potato (Solanum tuberosum L.) Guidelines for The Conduct of Tests for Distinctness, Uniformity and Stability. Geneva: International Union for The Protection of New Varieties of Plants.

Wulandari, A.N., S. Heddy, A. Suryanto. 2014. Penggunaan Bobot Umbi Bibit Pada Peningkatan Hasil Tanaman Kentang (Solanum tuberosum L.) G3 Dan G4 Varietas Granola. Jurnal Produksi Tanaman. 2(1): 65-72.

Nurchayati, Y. Setiari, N. Dewi, Nita K. M., Fella, S.. 2019. Karakterisasi morfologi dan fisiologi dari tiga varietas kentang (Solanum

tuberosum L. ) di Kabupaten Magelang Jawa Tengah. NICHE Journal of Tropical Biology. 2(2): 38-45.

Yunus, I., Putri, I. Y., \& Hafifah, H. 2018. Characterization of Pamelo Leaves (Citrus maxima (Burm) Merr) Aceh,
Maret, 2021

Vol. 18, Nol

Hal. 63-71

Author(s): Ismadi, et al

Indonesia. Journal of Tropical Horticulture, 1(1), 20-23.

Zahara, M., Hasanah, M., \& Zalianda, R. 2018. Identification of Zingiberaceae as medicinal plants in Gunung Cut Village, Aceh Barat Daya, Indonesia. Journal of Tropical Horticulture, 1(1), 24-28.

Zulkarnain, D.H. 2016. Uji Daya Hasil Genotipe Harapan Kentang (Solanum tuberosum L.) IPB Di Kabupaten Garut Jawa Barat. Skripsi. Institut Pertanian Bogor. Bogor 